\title{
Professor Jean-Paule Latgé wins Emil Fischer Carbohydrate Award 2015
}

Published online: 19 June 2014

(C) Springer Science+Business Media New York 2014

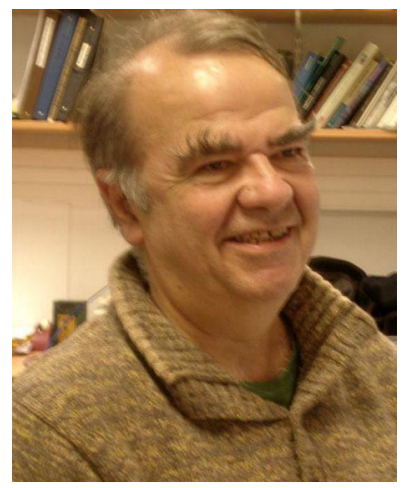

The Emil Fischer Carbohydrate Award has been established in 2008 by the European Carbohydrate Organisation (ECO) in order to honor active scientists distinguished with contributions of excellence to glycoscience. The Emil Fischer Award 2015 will be presented to Jean-Paule Latgé of the Institut Pasteur, Paris, France, in recognition of his outstanding accomplishments in fundamental and clinical aspects of the glycobiology of the human opportunistic fungal pathogen Aspergillus fumigatus.

Professor Latgé will present a plenary lecture on his reseach at the $18^{\text {th }}$ European Carbohydrate Symposium (Eurocarb18) that will be held on August 2-6, 2015, in Moscow, Russia (http://eurocarb18.com/). 